\title{
BILGISAYARLARIN EĞİTIMDE KULLANILMASI
}

(İngiltere ve Fransa Örnekleri)

\section{Jacques HEBENSTREİT*}

\author{
Çev: Yrid. Doẹ. Dr. Akif ERGİis**
}

\begin{abstract}
Bilgisayarların Eğitimde kullanılmasına ilişkin olarak A.B.D. örneği Jacques Hebenstreit'in Unesco için yaptı̆̆ çalışmadan Tïrkçe'ye çevrilerek "Eğitim ve Bilim" dergisinin 69. sayisında sunulmuştu. Bu kez Ingiltere ve Fransa örnekleri, gelişim ve yönelimleriyle birlikte, yine ayn çalışmadan dilimize çevrilerek sunulmaktadrr.
\end{abstract}

\section{İNGİLTERE (BİRLEŞIK KRALLIK) ÖRNEĞİ}

Birleşik krallık okul sistemi İngiltere, Galler, Kuzey İrlanda sistemi ve İskoçya sistemi olmak üzere ỉki ana bölüme ayrilabilir. Hükümet düzeyinde Eğitim ve Bilim Bakanlığı buluńmakla birlikte okul sistemi merkẹzi hükümetten çok yerel Eğitim Makamlarma bağli olduğundan yukarida sözü edilen her iki sistem de büyülk ölçüde yerinden yönetim esasına dayahdrr.

Ancak 1964 yllında bağımsız bir organ olarak kurulan ve Eğitim ve Bilim Bakanlıği ile Yerel Eğitim Makamlarından eşit ölçüde destek gören Oküllar Konseyi sayesinde bu iki destekçi arasında güçlü bir bağ bulunmaktadrr.

Okullar Konseyi program geliştiř̀i, eğitim araştırmalarnn yürütür, yeni eğitim programlarim onaylar ve devletin ilgili bakanına smav sistemine ilişkin öneriler götürür.

\section{The NDPCAL Projesi (1973-1978)}

The National Development Programme in Computer Assisted Learning (Bilgisayar Destekli öğrenme için Ulusal Kalkmma Programı)

* Jacques Hebenstreit, The Use of Informatics in Education-Present Stuation, Trends and Perstectives. Unesco, Paris, 1986.

** Eğitim Teknolojisi Anabilin. Dall Öğretim Üyesi. 
Eğition ve Bilim Bakanlığı 1973 yılında, bilgisayarların eğitimde bir yardımcı ortam olarak kullanılması için bağımsız bir kuruluş tarafından deneme ve geliştirme çalsșmalarmun yapturılması amàcıyla bütçesinden 2.000.000 sterlin ayırdı. Böylece sekreterlik hizmetleri de dahil, zaman zaman değişen ve ancak hị̧bir zaman 7 kişiyi geçmeyen kadrosuyla NDPCAL direktörlüğ̈ì 1973 yllında kuruldu.

En üstte yönetim ve kontrol politikasını oluşturan 22 üyelik program komisyonu bulunuyordu. Bu üyeler Eğitim Teknolojisi Kurulu, Okullar Konseyi, Yetkili Üniversite ve Sosyal Bilimler Araştırma Kurulları temsilcileri ile akademik, teknik ve endüstriyel örgütlerin danışmanlarindan oluşmakțaydı.

Proje 'önerileri, direktörlük ve proje çalı̧̧anlarınca geliştirildilkten sonra onaylanmak üzere program komisyonuna geliyordu. NDPCAL projesinin iki amacı vardı:

- Bilgisayar destekli öğrenme (Computer Aided Learning = CAL) ve CMI).

- Bilgisayar yönetimli ögretim (Computer Managed Instruction=

\section{Bilgisayar destekli öğrenme projeleri}

NDPCAL tarafından parasal destek verilen toplam 17 adet bilgisayar destekli ögrrenme projesi vardır:

- 9'u yưikseköğgetim ve daha ileri kademelerde,

- 3'ü ortaöğretimde,

-2 'si endüstriyel eğitimde,

-3 'ü askeri eğitimde.

NDPCAL'nin başarısında en önemli pay büyük oranda kurumlararası olan ve yükseköğretimde ve daha ileri kademelerde uygúlanan 9 - projeye aittir. NDPCAL projesinin sonlarına doğru tam 29 kurum aşağıda isimleri verilen bu 9 projeye katılmaktaydı.

Anılan projeler şunlardı:

- Bilgisayara dayalı ögrenme projesi.

- Mühendislik Bilimi Projesi.

- Bilgisayarlı Fizik Öğretim Laboratuvarı. 
- Klinik Teşhis/Tip.

- CALCHEM (Kimya).

- MATHLAB (Matematik).

- Üniversite Fen Programlarında Bilgisayarlar.

- Temel Matematik.

- Bilgisayar Destekli Öğrenme-Bir Üniversite Hizmeti.

Bu projelerin tümü 450 program paketinden oluşmaktaydı ve paketler $100^{\prime}$ den 10.000 'ne kadar değişen kod satır sayısındayd. Her bir pakete ortalama 700 kod satır düşmekteydi.

Kullanlan programlama dilleri FORTRAN, BASIC ve özel AUTHOR diliydi.

Program paketlerinin yazımı için akademik personel tarafından hàrcanan zaman genelde tüm programlarm yazımı için harcanan toplam sürenin $1 / 10^{\prime} u$ ìle $1 / 20^{\prime}$ si arașında olup bu süreyi aşmıyordu, İşin büyük bölümü ücretleri NDPCAL kaynaklarından karşılanmak üzere tutulan programcilar tarafından yapllyordu.

Çoğu yerlerde varilan bulgulara paralel olarak bir saatlik bir etkileşim paketinin hazırlanması 100-300 saat arası bir çabayı gerektiriyordu.

Öte yandan programclar ve akademik personel bilgisayar destekli öğrenmede deneyim kazandıkça, beklenenin tersine, yeni paketlerin üretimi ịçn gerekli olan zamanda bir azalma olmuyordu; çünkü zamanla programcılar ve akademik personel önceden izledikleri ve ustalaştıkları kolay yollar yerine yenilerini aradiklarmdan programlar giderek daha karmaşık bir yapıya bürünüyordu.

Terminallerin ortalama kullanım süreleri başlangıçta yapılan tahminlerin altında kalmıştır. Eğitim Teknolojisi Ulusal Komisyonunca yapılan bir verimlilik çalışmasına göre 1969 'da herbir țerminalin yılda 2000 saat kullanılacaği kestirimleri yapilırken, kurumlạrdan alınan bilgilere göre, geçirilen deneyim bunların herbirinin ylda $150-500$ saat arasinda kullanıldıklarını göstermiştir.

Okullarda yürütülen 3 Bilgisayar Destekli öğrenme projesi önemli olmamıştır. İkisi tarih biri 'de coğrafya ile ilgili olan bu projelerde okullar isteklerini posta ile bildirmekte ve bu istekler yine posta ile karşılanmaktayd. Bu projelere yapllan harcama NDPCAL tarafından Bilgisayar destekli öğrenmeye ayrılan kaynakların \% 6'sindan daha azdı. 
Endüstriyel eğitim alanındaki proje de bu kaynaklara ayrilan bütçenin $\% 6$ 'sından fazlasıni kullanmamıştır.

NDPCAL'nin yardımıla başlațilan Bilgisayar Destekli öğrenme projelerinin önemli bir kısmı çoğu kurumlarda sürdürülmüştür.

\section{Bilgisayar Yönetimli Öğretim (CMI Projeleri)}

Bilgisayar yönetimli öğretim (ya da öğrenme) bilgisayarların eğitim yönetiminde bir yardımcı olarak kullanımıyla uğraşmaktaydı (kayıt not verme, yöneltme, rapor etme vb. gibi).

Burada bilgisayar, öğretmenin bazı rollerini oynamaktaydı:

Testleri vermekte, testlerden aldıkları puanlar ışığında öğrencilerin izleỳeceği bir dizi öğrenme modülünü belirtmekteydi. Kuşkusuz ki bu, çok karmaşık bir yazılım sistemini içeren büyük bir projeydi.

Bilgisayar yönetimli öğrenme sistemiyle ilgili olarak gerçekleştirilen en önemli gelişme CAMOL (Computer Management of Learning = Öğrenmenin bilgisayarlı Yönetimi) olmuştur. Sistemin bir kismı ve uygulamada kullanılan eğitim materyalinin çoğu NDPCAL kaynaklannca geliştirilmiştir. Bu konuda başlıca iki uygulamadan söz edilmektedir:

. New University of Ulster'de Program Geliştirme ve Tasarım der* sindeki kullanımı ve

- Brighton Politechnic'te özellikle testlere not vermede, madde analizinde ve her yal kaydolan 600 öğrencinin kayıtlainnın tutulmasındaki kullanımı.

\section{Dağıtım}

NDPCAL, Bilgisayar destekli öğrenme ürünlerinin dağıtımını ve karşlıklı olarak değişimini sağlamak üzere iki küçük örgütü parasal olarak desteklemiştir. Bu örgütler program paketlerini ve testleri toplama ve bunlar üzerinde gereḳli değişilkikleri yapma işlerini yürütmekte ve üyelerin taleplerine göre dağıtımı gerçekleştirmekteydi.

$\mathrm{Bu}$ örgütler şunlardı:

1. The Physical Sciences Programme Exchange (PSPE $=$ Fen Bilimleri Programı Değişimi):

$B u$ örgüt fizik ve kimya ile ilgili küçük paket programları üyelerine dağıtmaktaydı. Üyelerin herbiri bu paketleri başka programlama dillerine çevirebilecek ya da bu programlamalarda değişiklik yapabilecek 
yeterlikte olan kimselerdi. Bu örgütün 50 üyesi bulunmakta ve bu üyeler tarafindan ayda 30 program istenebilmekteydi.

2. The Geographical Association Package Exchange (GAPE=Program Paketi Değiştirme Coğrafi Derneği):

$\mathrm{Bu}$ derneğin üyeleri bilgisayara ilişkin bilgileri hiç olmayan ya da çok az olan kimselerdi. Dèneğin, program paketlerine olan talebi karşılamak, kontrolünü yapmak, değiştirip düzeltmek üzere az sayıda personeli bulunmaktayd.

Dağıtım çok sayıdaki yorel merkezler aracılığıyla yapılmaktaydı. NDPCAL projesinin sonunda toplam $70 \mathrm{okul}$, yüksekokul, politeknik ve üniversiteye 270 program paketi kopyasının dağıtımı yapılmiştı.

\section{Maliyet}

NDPCAL Projesinin 1973-1978 yılları arasındaki toplam maliyeti 2.500.000 İniliz sterlini olup aşağıdaki kalemlerden oluşmaktaydı.

Bilgisayarlar, Terminaller:

Projede görev alan personel

Yolluk masrafları

Diğer harcamalar

$$
400.000 \text { sterlin }
$$$$
1.600 .000 \text { sterlin }
$$$$
100.000 \text { sterlin }
$$

400.000 sterlin

Issiriliğindeki kurumların toplam 2 milyon sterlin harcama yaptık: larını ve bunun yarısının da bilgiysayar donanımlarına ayrıldığını göz önüne aldığımızda projenin toplam maliyetinin 5 milyon sterlin dolaylarında olduğunu söyleyebiliriz.

\section{The Micro-Electronics Education Programme $(M E P=$ Mikroelek- tronik Eğitim Programı)}

1979'ların başında İngiltere hükümeti okullardaki mikroelektronik eğitim için 12.5 milyon sterlinlik bir destekleme programı duyuruyordu. Bu program başlamadı ya da başlatılamadı. Ancak 1980 Martında Eğitim ve Bilim Bakanlığı? 4 yıllık olmak üzere toplam 9 milyon sterlinlik bir destekle mikroelektronik eğitim programın başlattı. MEP ile İngiltere, Kuzey İlanda ve Gallerdeki ilk ve ortaokullar hedef alınmıştı. İskoçya için farklı bir program bulunmaktadir. (Scottish Micro-Electronics Programme $=$ Skoç mikroelektronik programı). 


\section{Hedefler}

MEP'in başlıca iki hedefi vardı:

1. Bilgisayarın öğretme ve öğrenme sürecinde;

- herbir çocuğa rehber olarak,

- küçük öğrenci gruplarına öğrenme yardımcısı olarak,

- tüm sınıfı kapsayan bir sistem olarak kullanılmasındaki en uygun yöntemi araştırmak.

2. Ayrı bir disiplin olarak ya da meveut konularm yeni elemanları olarak programda yer verilen yeni başlikları tanıtmak.

Çeşitli uzmanlık düzeylerine göre sözkonusu yeni başlıklar aşağıdaki gibiydi.

- Kontrol teknolojisinde mikro-elektronik

- Elektronik ve elektroniğin belli sistemlere uygulanması

- Bilgisayar çalışmaları

- Bilgisayara bağımlı çalı̧̧malar (bilgisayar yardımlı tasarım, veri yükleme ve veri işleme gibi)

- Kelime işlem ve öteki elektronik büro teknikleri

- Veri tabanlarından yararlanmak için bilgisayarın kullanımı

Programın yerleştirilmesi için öğretmenlere ilişkin başlıca üç ihtiyacın karşılanması gerekiyordu:

1. Öğretmenlerin "alandaki etkinlikler ve gelişmeler" konusunda bigilendirilmesi.

2. Öğretmenlerin "Bilgisayarları sinufta etkili kullanma yöntemi", konusunda eğitilmesi.

3. Öğretmenler tarafından kullanılacak materyallerin geliştirilmesi ve programla birlikte devreye girecek bilgisayarlarm incelenmesi.

Okullarda mikrobilgisayarlar bulunmamasına rağmen, MEP kaynaklarının çok sayıda donanımların satın alınmasina harcanmaması ilkesi benimsenmişti. Gerçekte, ortaokullara, mikoobilgisayar almalarında yardımcı olmak üzere Sanayi Bakanlığınca "Mikrolar Okulda" projesi başlatılmıştı. Toplam bir milyon sterlinlik bu projeyle ortaokullar İngiliz yapısı iki bilgisayardan birisine sadece yarı fiatına sahip olabileceklerdi; çünkü ücretin öteki yarisı proje tarafından ödenecekti. 
Yapılan bu planlamayla 1982 sonunda yaklaşık 5000 ortaokul birex bilgisayar sahibi olmuştu. Aynı yılın Temmuz ayırida ikinci bir "Mikrolar Okulda" projesi aynı koşullarda fakat bu kez 27.000 ilkokul için yürürlüğe konuldu.

Bu planların önemli bir özelliği satın alma koşulu olarak bir araç (bilgisayar) için en az iki öğretmenin temel eğitimden geçmesi konusunda gösterilen kararllıktı.

\section{Yönetim}

Eldeki az miktardaki para ile 109 yerel eğitim makamıyla doğrudan çalışmak olanaksizdı. Bu nędenle tüm yerel eğitim makamlan 14 bölge grubuna ayrıldı ve parasal kaynakların $2 / 3$ 'ünün bölgesel girişimlere $1 / 3$ 'ünün de ulusal girişimlere verilmesi kararlaştırıldı.

Her bölge merkezinde sınffta kullanılan video bantları, slaytları, işitsel kasetleri, kitapları ve öteki ilgili öğretim materyalleriyle bir yazılım kütüphanesini içeren bir danışma merkezi bulunmaktadır. Burada bulunan çoğu materyaller MEP tarafından üretilmiş olup bu materyalleri dışarıdan da ücreti karşılığı almak olasıdır.

Her bölgede yẹrel eğitim makamlarına bağlı olmak üzere 4 ayri konuda eğitim veren 4 merkez bulunmaktadır. Bu konular aşağida verilmektedir:

I. Teknoloji alanı (içeriği: Elektronik, Kontrol teknolojisi ve sanayideki uygulamalar)

2. Bilgisayar alanı (içeriği: Bilgisayar çalışmaları ve bir araç olarak bilgisayar)

3. Bilgisayara dayalı öğrenme alanı (Tüm eğitim programının öğretiminnde yardımeı bir araç olarak bilgisayarın kullanımı)

4. İletişim ve enformasyon alanı (içeriği İş çalışmaları ve Bilginin değişen rolü).

Her bölgede yukarıda suralanan alanlarin herbirinde birer bölge koordinatörü ve, tüm bölge koordinatörlerinin üstünde de yine her alandan olmak üzere birer ulusal koordinatör bulunmaktadır. Yukarıda sözü edilen bu danışma merkezlerinde çeşitli kurslar düzenlenmektedir:

- Yeni başlayanlar iģin 1-3 günlüik kurslar .

- Yeni başlayanlar kursunu bitirenler için 1 haftalık kurslar. 
- Uzmanlaşmak ya da ders yazilım programı yazmak isteyeneler için 3 aylık kurslar

. Eğiticilerin eğitimi kursu.

Her bölge için, kurslar düzenlemeleri amacıyla, ayda 60.000 İngiliz sterlini ayrlmaktadır. Kursun günlük maliyetinin 25 İngiliz sterlini olduğu dikkate alındığında ayrılan miktar, her bölge için, yılda 2400 öğretmen/gün demektir.

Ayrıca kurslar Açıüniversite, BBC ve yaygın eğitim yüksekokulu tarafından uzaktan eğitim yoluyla da verilmektedir.

\section{Ders yazilımı}

Ders yazlımların üretimindeki maliyet ve gecikmeler bu önemli kay-. nağın elde edilmesinde güçlüklere neden olmaktadır.

Birleşik Kurallıkta, gerekli kaynaklara ilişkin yapilan bir değerlendirme şu sonuçları vermiştir:

- Her okulun haftada bir kursu bilgisayar kullanarak işlemesi du* rumunda yaklaşık 1000 adet farklı yazilım paketine ihtiyaç olacaktır. Eğer bilgisayar bir ders için günde bir kere kullanılacak olursa o zaman bu sayı 5000 olarak belirlmektedir.

. 1983 sonlarında Birleşik Krallıkta yazlım paketlerini 10-30 İngiliz lirası arasında satan yaklaşı 60 yayınevi bulunmaktaydı ve koydukları bu fiatla çoğu yayınevi zarara girmekteydi.

- Yaşları 6 ile 14 arasında değiş̧en çocuklar için piyasada yaklaşık 250 yazılım paketi bulunmaktaydı.

- MEP yazllım paketlerinin öğretmenler tarafından üretilmesini teşvik etmekte ve Program Paketi Değiştirme Coğrafi Derneğinin (GAPE) bazı projelerini desteklemektedir.

. MEP Öğretmen gruplarına bölgesel düzeyde projeler geliştirmelerini önermekte ve geliştirilecek projelerin, Ulusal Okul Konseyince, eğitim yönünden değerlendirilmesinden sonra parasal açıdan desteklenebileceğini belirtmektedir.

Yazılım paketlerinin dağıtımı, önceki sayfalarda belirtilen Bölgesel Danışma Merkezlerinin görevlerinden birisidir. Bu merkezler NDPCAL zamanında kurulan ve üyelerinin bazılarnnca yazılan yazllım paketlerini tüm üyelerine dağıtmakla yükümlü CEDAR (Computer in Education 
As a Resource) ve SATROS (Science and Technology Regional Educatiotion) isimli örgütlerle iş̧irliği içerisinde çalışmaktadır.

Yazılım paketlerinin dağıtımına yardımeı olan başka kưuluşlar da bulúnmaktadır.

Öte yandan bilgisayarların eğitimde kullanılmasını teşvik etmek amacıyla ilkokullara alınan her bir bilgisayar için MEP ücretsiz olarak 30 adet yazılım paketi vermektedir.

\section{SONUĢ}

1973 'ten 1978'e kadar devam eden ve 5.000.000 sterlinin harcandığı NDPCAL projesinden sonra MEP 4 yll için 9.000.000 sterlinle ağırlığı öğretmenlerin eğitimine vermiş ve çok büyülk ölçüdeki yerinden yönetim biçimiyle eğitimi mümkün olduğunca öğretmenin ayağına götürmüştür. Donanımların alınmasını "her okul için bir bilgisayar". hedefiyle ve yarısı okul tarafından yarısı da proje tarafından ödenmek üzere teşvik etmiştir.

NDPCAL'nin ve MEP'nin tüm çabalarına rağmen yazllım paketleri halâ en az bulunabilen kaynaklar olup, bu özelliğini birkaç yıl daha sürdürecek ve bilgisayarların okullarda hızla yaylmalarına bir engel oluştưracak gibi görülmektedir.

\section{FRANSA ÖRNEĞI}

Bilgisayarların Fransada eğitime girişi tümüyle Fransız eğitim sisteminin yapısıyla ilgilidir. Bu nedenle bu sistemi tanımayanlar için birkaç sözcüklük bir giriş gerekli görülmektedir.

T'üm Fransız Eğitim sistemi, öğretmeninden bakanına kadar, hiyerarşik biçimde gü̧̧ı̈ bir merkezi yapıdadır. Ana okulundan üniversitesine kadar tüm öğretmenler hükümetin çalışanlarıdrr. Tüm programlax en ince ayrıntılarına kadar Milli Eğitim Bakanlığınca belirlenmiştir.

Zorunlu programlar, her ders ylinda, tüm okullarda aynı olmakta-. drr. Öğrotmenlerin haftalık ders saati yükleri de bakanlı tarafından belirlenmektedir. Tüm sınavlar da ülke düzeyinde aynıdır. Örneğin ortaöğretimin sonunda (18 yaş) Fransadaki tüm öğrenciler (yaklaşık 200 .000) aynı günde ve aynı saatte sınav merkezlerine gidip aynı smavları almak zorundadır. 
Milli Eğitim Bakanlığı 600.000 öğretmen ve profesörüyle, 500.000 büro elemanyyla, 13.000.000 öğrencisiyle ve ülkenin toplam bütçesinin yaklaşı \% 18'iyle Fransanın en büyüls şirketi olarak adlandirılmaktadir.

Birkaç yildır bu kesimdeki yoğunluğu ve merkeziyetçiliği azaltma çabaları sürdürülmektedir. Ülke her biri "Rektörlük" olarak anılan 27 akademik bölgeye ayrılmış ve başlarina bakanlıkça birer rèktör atanmıştrr. Her bölge kendi içinde 100 'er yöreye ayrılmış ve bunların başında da yine bakanlıkça atanan birer "müfettiş" yetkili kilınmıştrr.

Böylesi bir merkeziyetçi eğitim sistemi, sakıncalari da olsa, kararların alınmasında ve değişikliklerin yerleştirilmesinde, bilgisayarların Fransız eğitim sistemine girişinde olduğu gibi bazı avantajlar sağlanmaktadir.

\section{Ílkadımlar (1970-1976)}

1970'de altıneı beş yıllık hükümet planını hazırlayan komisyon bilgisayarların eğitime girmesi konusunụ tartışarak raporunda a) Bilgisayar uzmanı eğitimi, b) Bilgisayar Bilimine Giriş ve c) Büyük öğrenci kitlelerini "enformatic" ile tanışık hale getirmok için genel bilgi gibi konu ayırımlarinda bulundu.

Aynı yıl, bakanlık, komisyonun çalişmalarının sonuçlarını belclemeksizin bir yetkiliyi (Prof. W. Mercouroff'u) komisyon raporunun sonuçlarını uygulamaya aktarmak için görevlendiriyordu.

\section{Birinci Evrenin Eğitsel Amaçları}

Mercouroff "Bilgisayar bilimi"nin kesinlikle genel ortaöğretimde okutulacak bir ders olmadığım kabụ̂l ediyordu. Ona göre, bilgisayarın yapısi ve programlama teknik becerileri gerektirmekteydi. Mercouroff, Skinner'in beyinde geçen 'zihinsel süreci dikkâte almadan, öğrenciyi yeteneklleri girdiler ve çlktılarla değerlendirilen (verilen uyarana doğru ya da yanlış tepkilerde bulunan) bir kara kutu olarak gören davranış̧ıllk kuramına da karşı çıkıordu. Kara kutunun içini önemsediği, uyaranları ve tepkileri sadece göżlemek yerine bunlar arasındaki ilişkileri açıladığı için Skinner yakłlaşımının karşıtı olạn Piaget'in yaklaşımını daha gerçekçi buluyordu. Bu nedenle programlı öğretime iliş̧sin teşviklerden vazgeçilerek, öğretmenlerden tüm disiplinlerde benzetişime ve modeller oluşturmaya dayalı ders yazılım programları geliştirmeleri istendi. 


\section{Uygulamaya geçiş}

Doğ́al olarak birbiri peşi sıra farkh uygulamalara geçildi.

. Öğretmen eğitimi: 1970-1976 yılları arasında gönüllülü̈k esasına dayalı olmak üzere değişik disiplin alanlarından toplam 530 ortaöğretim öğretmeni, üniversitelerde bir akademik yıllık eğitimden geçirildiler. Aynı zaman zarfında 5000 'den fazla öğretmen de özellikle orta öğretimde kurulan ve bu kesime yönelik bilgisayar uygulamalarına ilişkin kısa süreli kurslardan geçirildiler. Eğitim sonlarında bu öğretmenler tekrar okullarındaki görevlerine verildiler; ancak herbirinden bilgisayarlan kendi alanlarında eğitim amacıyla kullanmalan ve öğrencilerinde denemeleri istenildi. Tüm bu çalışmalar (projeler) Fransız Ulusal Eğitim Araştırmaları Enstitüsü (Institut National de la Recherce Pedagogique $=$ INRP) tarafindan koordine edildi.

\section{Programlama dilinin seçimi}

Öğretmenlerce yazılan ders yazılım programlarının dặıtımını sağ: lamak ve programlarn bir dilden ötekine çevirerek yazmada harcanacak zaman ve parayı önlemek için Ecole Supérieure d'Elecctricte'teki Bilgisayar Bölümü tarafından özel bir programlama dili geliştirildi. Bu dịl, Language Symboligue d'Enseignement (= LSE), Fransizca konuş̧ulan, çok büyük oranda etkileşime elverişli, yeni başlayanlar için oldukç̧a basit ve aynı zamanda deneyimli programcılar için de yeterince etkili olabilen, ALGOL benzeri bir dildi.

\section{Bilgisayarlarm yerleştirilmesi}

Standart bir donanım yerleşim biçimi belirlenerek 1972 yılında bir dizi bilgisayarın siparişi yapıldr. 1976 'da, böylece, ortaokullarda 58 mikrobilgisayar yerleştirilmiş bulunuyordu. Bu mikrobilgisayarłar zaman paylaşımlı olup sekiz terminal ve bir bilgisayara bağlıydı; daha sonra da bunlara birer disk sürücü eklendi.

\section{Bu döneme ilişkin Sonuçlar}

58 ortaokuldaki deneme çalışmaları hemen hemen birbirinin ayniyd.' Donanımlara ilişkin gelişmeler 1976 yulında durdurułup, uygulamalar aynı donanımlarla 1980 yılına kadar sürdü. Aynı süre içerisinde INRP'den bir ekip denemelerin bir değerlendirmesini yapmaya başladı. $\mathrm{Bu}$ değerlendirmenin sonuçları şunlardır: 
- Deneme çalışmaları süresince donanımların bulunduğu okullarda her yıl 45.000 öğrenci (toplamın I/2 si) ve $1000^{\circ}$ den fazla öğxetmen (toplamın $1 / 6$ sı) bilgisayar kullanmıștı.

- Bilgisayarlar ortalama olarak haftada 32 saat; ylda 25 hafta (yrlda 800 ) saat kullanulmıştı.

- Öğretı́nenler tarafından yazılan 4,00 kursluktan da fazla bir yazılım seti INRP tarafından merkezde toplanmış, değerlendirilmiş ve dağıtimı yapılmıştı.

- Enformatics ile ilgili, genel bilgiler etkili bir biçimde verilmiş bazı. gönüllü öğrenciler ise, bunlarm da ötesinde, bilgisayar bilimine giriş kursu almışlardı.

- Sadece Matematik ve Fen'de değil tüm disiplinlerde "Enformatics'e Giriş" kursları gerçekleştirilmişti.

Bunlarm ötesinde değinilmesi gereken başka bulgular da vardı:

- Resmi yönergelere rağmen programlı ögretim yöntemini kullanan çok sayıda yazılım paketleri bulunmaktaydı (Özellikle Fransızca Dil Bilgisi ve Yabance Diller)

- Deneysel bilimlere ilişkin ders yazlım paketlerinin çoğunda benzetişim ve model oluşturma yöntemi kullanılmıştı.

- Bir yıllıl tam zamanlı eğitim süresince, bilgisayarın eğitimde kullanılmasından çok, bilgisayarın yapısına ve programlamaya daha fazla önem verilmiş; bu da bazı -sakıncalı sonuçlara yol açmıştır. Örneğin, öğretmenlerin azımsanmayacak bix bölümü. bu. makineden çok etkilenerek "bilgisayar bilimi" nin ayrı bir disiplin olarak öğretilmesi görüşünü şartsız olarak destekleyecek biçimde bilgisayarce kesilmişlerdi. Bu tutumun arkasında, muhtemelen, tarih ya da cebir ögretmek yerine bilgisayarla oynamanın daha eğlenceli olduğu görüşü yatmaktaydı. Başka bir sakıncalı sonuç ta öğretmenlerin programlama dilinin kullanılısına ilişkin çalışmalarda büyük güçlülklerle karşılaşmaları ve bu nedenle de ders yazılım paketinin hazıllanmasında zor olanın, davranışsal hedeflerin. tanımlanması değil, programın yazılması olduğunu düşünme eğilimi göstermeleriydi. Oysa kesin sonuçlar gösteriyordu ki, önemsiz denilebilecek ya da kalem-kağıtla ulaşabilecek türdeki hedef davranışlan kazandırmak için hazırlanan bazı program paketlerinin gerçekteki değeri çok azd.

- Bir paket program hazrlamanin zor ve zaman alıcr bir etkinlik olduğu inancı tüm öğretmenlerce paylaşılmassna rağmen, bu öğretmen- 
lerin çoğu baş̧aları tarafindan yazılan program paketlerine çok eleştirisel bir tutum sergilemişlerdir.

Aynı dönemde başka yerlerde başka projeler de gerçekleştirilmiş olmakla birlikte, Fransa'daki "Bilgisayarların Eğitimde Kullanulması" örneğini bir başka yerdekiyle karşlaştırmak güç olmaktadır. Belki de karşılaştırılabilecek tek örnek 1973-1979 arası süren Birleşik Krallıktaki 5 milyon dolarlık bütçeli NDPGAL projesidir. Hatırlanacağı gibi NDPCAL özellikle üniversite düzeyini hedef almıştı. Onyedi projeden sadece üçü ortaöğretim düzeyinde ve her üçü de tarih ve coğrafya alanındaydı.

Ayrrhkklarına rağmen her iki proje göz önüne alınarak yapılan bir değerlendirmede benzer noktalara işaret edilebilir. Bunlar;

1) NDPCAL bütçesinin $\%$ 60'1 personel giderleri için harcantrken Fransa örneğinde bütçenin $\% 70$ ' ket programların yazılması için harcandı.

2) Değerlendirmeler, NDPCAL projesinde terminallerin yılda ortalama 500 saat; Fransa örneğinde ise yllda ortalama 800 saat kullanıldığını ortaya koydu.

3) Her iki projede de bir saatlik bir etkileşim programinın yazilması için ihtiyaç duyulan süre 100 saat ile 300 saat arasında değişiyordu.

4) Her iki projede de en iyi program paketleri ekiplerde görev alan öğretmenlerce üretildi.

5) Her iki projede de öğretim yöntemi olarak ağtrlık benzetişim ve model oluşturmaya verildi. Öğrencilerin bu yönteme karșı tutumlarx olumluydu.

6) Her iki projeyi de yaşadıktan sonra uzmanlar, BİLGİSAYAR DESTEKLI ÖĞRETİM'in başka șeyin yerini almayacağ̀, ancak varolanlara çok şeyler ekleyeceği sonucuna vardurlar.

\subsection{Mikrobilgisayar Planı}

1979'a kadar ek hafıza olarak disk sürücüleri kullanan 8 bite'lık mikro işlemli birinci kuşak bilgisayarlar bulunmaktaydı. Bu bilgisayarlar çok yönlülüls, güvenilirlik ve uygulama sistemindeki incelikler açısından profesyonel standartlardan uzaktı. Ne var ki, gerekli tüm özellikleri taşıyan ikinci kuşak mikrobilgisayarlar kapıdaydı. Bu nedenle Fransa Eğitim Bakanlığı ile Sanayi Bakanlığı 11-18 yaş arasındaki öğrenci- 
lerin yararlanmaları için ortaokullara 10.000 bilgisayar yerleştirmek üzere, 1979 ylunda, ortaklaşa bir plan yaptılar.

Bu planı uygulamaya, koyaṛken 1979'ların başındaki durumu da dikkate almak gerekmekteydi. 0 zamanlar elde, kişisel bilgisayarların değil, zaman paylaşımlı bilğisayarların eğitimde kullanılmasıyla edinilen deneyimler bulunmaktayd. Daha önceki projeyle 600 öğretmen ders yazılım paketlerini hazurlayabilecek düzeye gelecek biçimde yetiştirilmiş; 5.000 ögretmen de bilgisayar biliminin temelleri ve bilgisayarların eğitimde kullanılması konusundaki kursu tamamlamıştı. Ayrıca 500 den fazla taşınabilir ders yazılım paketini içeren bir banka bulunmaktaydr. Bu da açıktı ki birinci kuşak mikrobilgisayarlar eğitimde kullanılmak üzere iyi bir seçim değildi. Bu dönemde ev terminallerini de içeren bir ulusal veri aktarım ağı harekete geçiyordu.

1979'lardaki bu durum saptaması başhıca 4 kararın alınmasına yol açtı.

1. Her seferinde en elverişlisinin seçilerek $1980^{\prime}$ de $400 ; 1981^{\prime}$ de 800 adet olmak üzere toplam 1200 mikrobilgisayarın kurulması.

2. Kişisel bilgisayarla gerçekleştirilecek iki yıllık bir denemeden sonra eğitim açısından kişisel bilgisayarlarla yerel zaman paylaşımlı bilgisayarların tümüyle karşılaştırılması ve kullanılacak en iyi çeşidin belirlenmeși.

3. LSE'nin standart dil yapılması (bunun için Fransa Ulusal Standartlar Bürosuna başvuruda bulúnulmuştu). Programları bir dilden ötekine çevirme sorunlarından ve masraflardan kaçınmanın ötesinde bu kararı destekleyen başka iki neden bulunmaktaydı. Birincisi, tümüyle kullanılan ve değerlendirilen ve ayrıca kullananların \% 70'i tarafından "çok iyi" ve "mükemmel" olarak nitelendirilen yaklaşık 500 programllk mevcut bankadan azami düzeyde yararlanmaktı. İkincisi, öğretmenleri bilgisayar biliminin temellerine ve programlamanın en ince ayrıntılanna kadar, uzun ve karmaşık bir eğitim sürecini gerektiren paketlerle desteklemek yerine, alanlarıyla ilgili olarak hazirlanmış ve kullanımı kolay bir ders yazılımı paketiyle destekleyerek öğretme öğrènme süreçlerinde bilgisayar kullanmanın yararlarına inandırmak daha kolay olmaktayd..

'Şu da açıtı ki gelecekte öğretmenlerin çoğu program paketlerinin sadece kullanıcılan olacak, ancak küçülk bir kısmı bunların tasarımı ve yazımı ile ilgilenecekti. 
4. 1979-1980 akademik yılı için, önceden bir yllık eğitimden geçen öğretmenler arasından seçilen 40 öğretmene ücretleri düzenli olarak ödenmek üzere bir yıllık süre verilmesi ve bunlarin bu sürè zarfinda mikrobilgisayarlarm verildiği okullara giderek (her okula 8 mikro) buradaki öğretmenler için kısa seminer düzenlemeleri. Bu 40 öğretmen düzenleyecekleri seminerlere. ilişkin olarak 1979 Ẹkiminde 3 haftalık bir seminerden geçirilmişlerdi.

\subsection{0 mikrobilgisayar planı}

1981'de MITTERAND'ın Cumhurbaşkan seçilmesinden sonra 10.000 mikrobilgisayar projesi birkaç aylığına dondurularak iki profesörden (C. Pair ve Y. Le Corre) bir komisyon oluşturulmuş ve bu komis* yondan yeni bir rapor hazurlanması istenmiştir. Hazırlanan raporda projenin ayñ amaçlarla sürdürülmesi gereğine değiniliyor ve 12 ortaokulda "Enformatics"in seçmeli bir ders olarak 16-18 yaş grubuna okutulacağı küçük bir denemenin yapılması ve değerlendirilmesi tavsiye ediliyordu.

Rapor aynı zamanda araçları olan okullarda 100 saatten az olmamak üzere seminerler verilmesini öngörüyor ve 1981 ekiminde başlatılan tam zamanlı ( 30 haftalık) eğiticilerin eğitimi kursunun içeriğini de belirliyordu.

Ayhr yıl özellikle üniversitelerde olmak üzere eğiticilerin öğretmenlerinin 750 saatlik bir eğitim programıla eğitilmeleri için onbir adet Bilişim Eğitimi ve Eğitsel Uygulamalar Merkezi kuruldu. Anılan 750 saatin $300^{\prime} \ddot{u}$ genel bilişim, programlama yöntemleri vb. için; $300^{\prime} \ddot{u}$ bilgisayar destekli öğretim için; 150'si ise öğretmenlerin eğitiminin gelecekteki etkinliklerinin planlanması için ayrılmıştı.

1982 ylhnda bu onbir merkezde 230 öğretmen eğitimden geçti. 1983'te bu 230 ögretmen araçlarını alan okullarda tam zamanlı olarak öğretmenlerin eğitimi seminerlerinde görev yaparlarken merkezlerin sayısı $11^{\prime}$ den $15^{\prime} \mathrm{e}$ çıkıyor ve bu kez 300 öğretmen eğitimden geçiyordu.

1984 yılında merkezlerin sayısı $20^{\prime}$ ye ve bir akademik yılda eğitimden geçenlerin sayısı $500^{\prime}$ e yükseldi. Hedef, gelecek birkaç yılda her akademide bir merkez kurmaktı (toplam 27 akademi bulunuyordu).

Aynı sürelerde 100 saatlik kisa seminerlerden geçen öğretmenlerin sayısı doğal olarak artıyordu. 1981-1983 döneminde yaklaşık 20.000 öğretmen eğitilirken 1983-1984 akademik ylında bir başka 20.000 öğretmen eğitimden geçiyordu. 
$1981^{\prime}$ den s̀onra ritmik olarak artan öğretmen eğitimine paralel ola. rak okullara yerleştirilen bilgisayar donanımlarında da artışlar oldu. 1981 sonunda yerleștirilmiş olarak toplam 1200 bilgisayar bulunuyordu (bir okula 8 mikrobilgisayar ve bir bilgisayar); bu sayı 1983 sonunda 6000 'e yükseldi.

Ve aym 1983 yılında Milli Eğitim Bakanlığı 10.000 mikrobilgisayar projesini yürürlükten kaldurlarak yerine daha ileri bir adımla 1988 yıInnà kadar 100.000 öğretmenin eğitimini de içeren 100.000 mikrobilgisayar projesinin konulduğunu açılkhordu. Bu yeni planın bir bölümü gereğince 1984 yılında ilk, orta ve lise düzeyinde olmak üzere toplam 12.000 bilgisayar okullara yerleştirildi.

\section{5 planı}

Konuya ilişkin olarak son birkaç yıllhk Fransız Hükümeti'nin uygulama programı aşağıdaki gibi özetlenobilir.

Araç-Gereç maliyeti

(A.R.D. Milyon Dolari)

Öğretmenlerin Eğitimi

(A.B.D. Milyon Dolar)

Eğilimde geçeu öğretmen sayısı

Yerleştirilen mikrobilgisayar sayısı

\begin{tabular}{ccc}
$\frac{1982}{7.8}$ & $\frac{1983}{8.8}$ & $\frac{1984}{24.7}$ \\
\hdashline .5 & 9.5 & 20 \\
4.200 & 11.000 & 20.000 \\
3.000 & 15.000 & 40.000
\end{tabular}

25 Ocak 1985'te Başbakan Laurent Fabius düzenlediği bir basın toplantısında 1985 yilı sonundan önce okullara girecek başka bir $120.000^{\circ}$ lik mikrobilgisayar ile 100.000 öğretmenin eğitimi planını resmen açılkladi.

Böylece 11.000.000'luk ögrenci sayısına karşılık toplam 160.000 bilgisayar ve 150.000 eğitimden geçmiş öğretmen sayısına ulaşlıyordu:

Konuya ilişkin olarak 1985 mali yılındaki harcama kalemleri A.B.D Doları olarak aşağıdaki gibiydi:
Araç-Gereç
150.000 .000
A.B.D. DolarI
Öğretmen Eğitimi
25.000 .000
A.B.D. Doları
Ders Yazllım
A.B.D. Doları
200.000 .000
A.B.D. Dolarn 


\section{Amaçlar}

Yeni planin hedefi okullarda kullanılmakta olan bilgisayarlara 120.000 tane daha eklemekten çok daha genişti. Plan "Herkes için Bilişim" olarak adlandırlıyor ve tüm nüfusu bilgisayar kullanımina alıştırmayı amaçlıyordu. Bu amacı gerçekleştirmek için okulların ders saatleri sonrasında açık tutulması ve vatandaşların, daha önceden eğitimden geçmiş olan öğretmenleṛin denetimindeki bilgisayara giriş kurslarmı ücretsiz olarak izlemeleri kararlaştırıldı.

\section{Öğretmenlerin Eğitimi}

Normal okul gününün neden olabileceği kaygılardan kaçınılması için ve gönüllülülk eșasma dayalı olarak tatil günlerinde düzenlenen öğretmenlerin eğitimi çalışmaları için 3 dönem elverişliydi: Paskalya tatili, yaz tatili ve Kasım ayı başındaki bir haftalık tatil.

Eğitim çalı̧̧maları 20-30 kişilik öğretmen gruplarıyla yapılacak ve 5 tam gün sürecek .biçimde düzenlenmişti. Bu süre içerisinde öğretmenlere aracın ve araçlarla birlikte okula gelen birbirinden farklı çeşitli yażlímların nasıl kullanılacağı öğretiliyordu.

1985'teki iki haftalık páskalya tatilinde, önce, 500 grup öğretmenin eğitimden geçirilmesi planlandı, ancak gönüllü öğrètmen sayısımın fazlalığı Ĕ̆itim Bakanlığını toplam 19.000 öğretmeni kapsayan 620 grupluk bir eğitim programı düzenlemeye itti. Yaz tatili için ise (14 Temmuzdan Ağustos sonuna kadar) 1000 merkezde 5000 toplantı planlanmıști ve son toplantılar okullarm bir hafta tatil olduğu Kasım ayı başıฺ̣da yapllacaktı. Tatilleri surasında yapılan eğitim toplantılarına katılmalarına teşvik için yol vb. masraflar dahil her öğretmene 130 A.B.D. doları veriliyordu (hemen belirtmek gerekir ki gidilen yollar merkeziyetci olmayan bir düzenlemeden ötürü uzun değil kısaydı).

\section{Yazilım}

Başlangıçta ,donanımı olan her okulun ayn zamanda 50 yazılım paketini içeren yaztlım kutusunu da alması kararlaştırılmıştı.

Fransadaki yerli ve yabancı şirketlere ürünlerini bakanlığa önermeleri konusunda çağıı yapıldı. Yapılan öneriler arasından bir seçim yapmak üzere küçük bir "yazilım komitesi" oluşturuldu. 
Bu yazılım komitesi, hareket planında, aşağıda belirtilen noktaları benimsedi:

1. Yazılım kutúsundakilerin $\% 60$ tan fazlası tam anlamıyla eğitim yazılımı olmalı: matematik, fizik, biyoloji, tarih, coğrafya, fransızca, yabancı diller, güzel sanatlar vs. (oyunlai hariç).

2. Yazilım paketinin \% 10 ile \% 20'si genel aygıtları ya da uyarlanacak bağlantıları içermeli: metin işleme, vèri tabanı bağlantiları, bilgisayar yardımlı çizim vs.

3. Seçilen her bilgisayar teknik olarak kontrolden geçirilmeli.

4. Teslim edilen ve komitece seçilen heṛhangi bỉr yazılım paketinde yabancı dil kullanilıyorsa bu Fransızcaya çevrilmeli.

5: Yazılım için ayrılan bütçenin sadece yarısı yazılım kutuları için kullanılmalı, öteki yarısı ise yazılım komitesi tarafından yukarıda sıralanan ölçütlere göre derlenerek resmen okullara gönderilecek yazllım kataloglarından kendi seçimlerini özgürce yapabilmeleri için okullara açık kredi olarak brrakılmalı.

6. Tüm araçlar ya CP/M ya VS/DOS ya da en azından ikisinden oluşan sistemle çalışmalı; ayrica her kutuda üç dil bulunmalı: BASIC, LSE ve LOGO (çıacak yazılım paketlerinde daha çok dil bulunacak).

7. Bir ya da iki anahtar dil bulunmali.

8. Yazılım kutusunda sadece birkaç eğitsel oyun bulunmalı (o da özellikle ders saatlerinden sonra "tenefüslerde" izleyicileri tekrar içeri çekebilmek için).

Komiteye toplam 696 yazlim paketi teslim edildi: Bunlarn yaklaşık 200'ü bakanlığın bir kuruluşu olan Eğitim Dokümantasyon merkezinden ücretsiz olarak sağlandt.

\section{Donanim}

$\%$ 98'i Fransız yapımı olan değişik tipteki araçlar okullara verilecek \% 2'lik kısım ise yanbancı bilgisayarlara açık olacaktı.

400 'den daha az öğrencisj olan, 33.000 okula Thomson Tot-70; 11.770 ilk ve ortaokul ile 500 lise "Nano reseau" adı verilen milkrobilgisayar ve ayruca her liseye ụç adet profesyonel tür bilgisayar verilecekti. 